\title{
Human Immunodeficiency Virus Infection of Helper T Cell Clones Early Proliferative Defects Despite Intact Antigen-specific Recognition and Interleukin 4 Secretion
}

\author{
Jeffrey Laurence, ${ }^{\star}$ Steven M. Friedman, ${ }^{\ddagger}$ Elliot K. Chartash, ${ }^{\ddagger}$ Mary K. Crow, ${ }^{\ddagger}$ and David N. Posnett \\ * Laboratory for Acquired Immunodeficiency Syndrome (AIDS) Virus Research, Division of Hematology-Oncology, \\ ${ }^{\ddagger}$ The Hospital for Special Surgery, and ${ }^{\S}$ Division of Allergy and Immunology, Department of Medicine, \\ The New York Hospital-Cornell Medical Center, New York, New York 10021
}

\begin{abstract}
HIV selectively inhibited the proliferative response of clonal CD4+ $T$ lymphocytes to alloantigen while other alloantigendependent responses were unperturbed. Specifically, impaired blastogenesis could be dissociated from alloantigen-specific induction of the $B$ cell activation molecule $C D 23,1 \mathrm{~L}-4$ release, and inositol lipid hydrolysis. In addition, membrane expression of pertinent $T$ cell receptor molecules, including $\mathrm{CD2}, \mathrm{CD} 3$, and $T$ cell antigen receptor $(\mathrm{Ti})$, remained intact. Using two MHC class II-specific human CD4+ helper $T$ cell clones, the proliferative defect was shown to be an early consequence of HIV infection, occurring within $4 \mathrm{~d}$ of viral inoculation and preceding increases in mature virion production. It was generalizable to three distinct methods of $T$ cell activation, all independent of antigen-presenting cells: anti-CD3 mediated crosslinking of the CD3/Ti complex; anti-CD2 and phorbol 12myristic 13-acetate (PMA); and anti-CD28 plus PMA. These abnormalities were not mitigated by addition of exogenous IL-2, even though expression of the IL-2 receptor (CD25) was unaltered. These studies define a selective blockade in $T$ cell function early after HIV exposure that could serve as a model for certain in vivo manifestations of AIDS.
\end{abstract}

\section{Introduction}

One puzzling aspect of the pathogenesis of AIDS is the long incubation period during which CD4+ T cells, monocytes, and possibly other cells are thought to be infected with the etiologic retrovirus, HIV. Absolute numbers of $\mathrm{CD} 4+$ cells and the CD4:CD8 helper/inducer to suppressor/cytotoxic T lymphocyte ratio may be within normal limits, yet certain measures of cellular immunity are markedly perturbed (1). These early events following HIV infection, particularly qualitative changes in immune reactivity, are poorly understood.

To examine antigen-specific responses in vitro we used helper T cell clones reactive with two MHC class II (MHC-II) ${ }^{1}$

Address reprint requests to Dr. J. Laurence, Division of HematologyOncology, The New York Hospital-Cornell Medical Center, 525 East 68th St., New York, NY 10021.

Received for publication 8 August 1988 and in revised form 12 December 1988

1. Abbreviations used in this paper: APC, antigen-presenting cells; IMDM, Iscove's modified Dulbecco's medium; LTR, long terminal repeat; MHC II, MHC class II; PKC, protein kinase C.

J. Clin. Invest.

(c) The American Society for Clinical Investigation, Inc $0021-9738 / 89 / 06 / 1843 / 06 \quad \$ 2.00$

Volume 83, June 1989, 1843-1848 determinants. We showed that loss of alloreactivity is a direct consequence of HIV infection (2). It was independent of cell viability and could be prevented by treatment of target cells with an anti-HIV agent (2). This system was used here as a model to examine perturbations in $T$ lymphocyte function early after HIV exposure. We now demonstrate that HIV selectively inhibits the proliferative response of clonal $\mathrm{T}$ cells to alloantigen, while other alloantigen-specific responses remain intact. This defect is generalizable to several different methods of $\mathrm{T}$ cell activation. MHC-II antigen-specific upregulation of IL-2 receptors, IL-4 production, and inositol lipid metabolism are not decreased, and in certain instances may be augmented.

\section{Methods}

Cells. PBMC were isolated from the heparinized venous blood of HIV seronegative donors. The E-rosette depleted subpopulation (3) was used as a source of antigen-presenting cells (APC). The derivation and specificity of the $T$ cell clones have been previously detailed $(2,4,5)$. A57 is an HLA-DR+, CD3+, CD4+, CD8-, IL-2-dependent T helper cell line that proliferates in response to HLA-DR2+ APC. 86 is a T inducer clone of identical phenotype that demonstrates HLA-DR1 specificity. Both clones were grown in Iscove's modified Dulbecco's medium (IMDM; Gibco Laboratories, Grand Island, NY) supplemented with $10 \%$ FCS and $64 \mathrm{U} / \mathrm{ml}$ nonrecombinant IL-2 (ElectroNucleonics Inc., Fairfield, NJ).

$H I V$ infection of $T$ cell clones. Definitions of HIV stocks and infectious titers $\left(\mathrm{ID}_{50}\right)$ were previously outlined $(2,6)$. A57 or 86 cells were plated in macrowells (Costar 3512; Costar, Data Packaging, Cambridge, MA) at $0.5 \times 10^{6} / \mathrm{ml}$ in IMDM plus $10 \%$ FCS plus IL-2. They were exposed to $1,000 \mathrm{ID}_{50}$ of HIV viral stock, the medium was completely changed at $18 \mathrm{~h}$, and one-half of the medium removed and replenished with IMDM plus $10 \%$ FCS plus $10 \%$ IL-2 every 3-4 d thereafter.

CD23 induction and assays for IL-4. CD23 (BLAST-2) is a 45-kD B cell activation antigen. Its expression is induced by antigen-specific $T$ helper cells (7) and IL-4 (8). $0.3 \times 10^{6}$ viable 86 or A57 cells, either uninfected or harvested $1,2,3,4$, and $7 \mathrm{~d}$ post-HIV exposure, were washed with PBS and cocultured with $1.0 \times 10^{6} \mathrm{APC}$ of appropriate or irrelevant HLA-DR allotype for $18 \mathrm{~h}$ at $37^{\circ} \mathrm{C}$ in a total volume of 0.5 $\mathrm{ml}$. IL-4 levels were determined in a bioassay involving induction of CD23 on resting tonsillar B cells as previously detailed (7) using antiCD23 MAb EBVCS2 (7).

Proliferation assays. $2 \times 10^{4}$ viable cells were resuspended in $0.1 \mathrm{ml}$ IMDM + 10\% FCS in round-bottom chambers of 96-well microtiter plates. For alloantigen-mediated stimulation, $1 \times 10^{5}$ irradiated APC carrying either the appropriate or irrelevant allodeterminants were used. For MAb-driven mitogenesis, reagents were used at a 1:400 dilution of ascitic fluid (anti-CD2 and anti-CD28), or a 1:20 dilution of hybridoma culture supernatant. Cultures, assayed in triplicate, were maintained for $36 \mathrm{~h}$, the last $18 \mathrm{~h}$ of which contained $0.1 \mu \mathrm{Ci}$ of $\left[{ }^{3} \mathrm{H}\right]$ thymidine (New England Nuclear, Boston, MA).

Monoclonal and polyclonal antibodies. The MAbs used included: anti-CD3 454.3, (courtesy of W. Stohl, University of Southern California); anti-CD4 (FFB2.3); anti-CD25 (anti-Tac; T. Waldmann, Na- 
tional Institutes of Health); anti-CD23 (MAb EBVCS2 [7]; Dr. W. Sugden and Dr. S. Metzenberg, McArdle Laboratory for Cancer Research, Madison, WI); anti-CD2, T11 $1_{2}$ subtype (MAb 9:6 [9]; P. Martin, Seattle, WA); and anti-CD28 (MAb 9.3 [10] P. Martin). The T cell receptor was identified by two reagents: MAb WT31, reactive with the alpha/beta chain $T$ cell receptor complex, and an anti-clonotypic MAb, Ti-19.1, which immunoprecipitates the alpha and beta chain heterodimer exclusively from 86 cells (Posnett, D. N., unpublished observations). Ti-19.1 is also mitogenic for 86 cells when added in solution at a 1:20 dilution of hybridoma supernatant together with $\mathrm{Fc}$ receptor-positive cells of any HLA-DR allotype. HIV antigens were detected using a MAb recognizing envelope glycoprotein gp120 (DuPont Instruments, Wilmington, DE) and human polyclonal IgGs Sec and Cul. The latter reagents were isolated from sera of asymptomatic HIV-1 seropositive individuals by Zeta-chrom 60 ion exchange chromatography disc (CUNO, Inc.; Meriden, CT) and characterized by radioimmunoprecipitation of HIV-specific proteins as previously described (6).

Immunofluorescence assays. Indirect immunofluorescence was performed with mouse anti-human MAbs counterstained with fluorescein-conjugated $F\left(a^{\prime}\right) 2$ fragments of goat anti-mouse IgG (Tago, Inc., Burlingame, CA), or with polyclonal human IgGs counterstained with fluorescein-conjugated $F\left(a b^{\prime}\right) 2$ fragments of goat anti-human IgG, IgA, and IgM (Cappel Laboratories, Cochranville, PA) (3).

Measurement of $I L-2$ binding. IL-2 receptor binding was determined by the method of Robb et al. (11) using cells uninfected or 4-7 d post-HIV inoculation, and serial dilutions of ${ }^{125} \mathrm{I}-\mathrm{IL}-2$ (New England Nuclear). The specificity of the receptor-ligand intermediate was determined by competitive inhibition of binding using unlabeled antiCD25 antibody.

Inositol (poly)phosphate analysis. T cells were labeled with myo$\left[{ }^{3} \mathrm{H}\right]$ inositol in inositol-free RPMI-1640 medium as previously described (12). Inositol phosphates were extracted from $T$ cells exposed to various signals by the addition of $1 \mathrm{ml}$ of chloroform/methanol/ concentrated $\mathrm{HCl}(100: 100: 1, \mathrm{vol} / \mathrm{vol} / \mathrm{vol})$ followed by $0.2 \mathrm{ml}$ of 10 mM EDTA (12). After centrifugation the upper phase (water soluble) was isolated from the lower phase (lipid soluble), washed with $0.2 \mathrm{ml}$ of preequilibrated lower phase buffer, dried under $\mathrm{N}_{2}$, redissolved in $1 \mathrm{ml}$ of $0.1 \mathrm{M}$ formic acid, and applied to 1-ml columns of anion exchange resin AG1-X2 (Bio-Rad Laboratories, Richmond, CA) that had been swollen in $0.1 \mathrm{M}$ formic acid containing $5 \mathrm{mM}$ myo-inositol (12). The columns were sequentially washed with $0.1 \mathrm{M}$ formic acid to elute inositol, followed by $1 \mathrm{M}$ ammonium formate/0.1 $\mathrm{M}$ formic acid to elute inositol phosphates. Both inositol and inositol phosphates, which included inositol mono-, bis-, and triphosphates, were recovered and ${ }^{3} \mathrm{H}$-labeled radioactivity determined by liquid scintillation counting.

\section{Results}

Growth characteristics of clone 86. The dependence of our alloreactive clones on IL-2 $(4,5)$ was reestablished for 86 cells. Between days 4 and 9 of culture viable cell recovery in the absence of IL-2 was only $44.9 \%$ of that achieved by cells maintained in medium supplemented with $64 \mathrm{U} / \mathrm{ml} \mathrm{IL-2}$. Response to exogenous IL-2 or IL-4 is difficult to detect among cells maximally stimulated by the appropriate alloantigen. In the absence of APC bearing the relevant alloantigen, $64 \mathrm{U} / \mathrm{ml}$ IL-2 led to a 5.1-fold increase in stimulation index at $48 \mathrm{~h}$ after IL-2 exposure and $5 \mathrm{U} / \mathrm{ml}$ recombinant IL-4 led to a 4.9-fold increase.

$H I V$ infection. 86 cells were exposed to $1,000 \mathrm{ID}_{50}$ of stock HIV on day 0 , washed $18 \mathrm{~h}$ later, and fed every 3-4 d with fresh medium containing IL-2. Indirect immunofluorescence was performed on days $1,3,6,8$, and 10 post-HIV exposure. A rapid rise in the number of cells expressing HIV antigens, reflecting adherence of HIV virions to the membranes of $>50 \%$ of the clonal population, is noted on day 1 (Fig. 1, $A$ and $B$ ). A secondary rise in the expression of HIV antigens, detected by polyclonal Sec IgG and MAb gp 120, is seen by day 4. In each of four experiments, $<10 \%$ of 86 or A57 cells expressed HIV-specific proteins on day 3, rising to $10-50 \%$ by day 8 and $50-75 \%$ by day 12 . Through day 8 these cells maintained viability equivalent to control cultures, $85 \pm 9 \%$ by trypan blue dye exclusion. In addition, little variation in total cell concentration was noted through day 8 . For example, mean viable cell recovery was equivalent for both uninfected $(86 \%)$ and infected $(83 \%) 86$ cells on day 4 , the point at which initial proliferative determinations and subsequent metabolic and
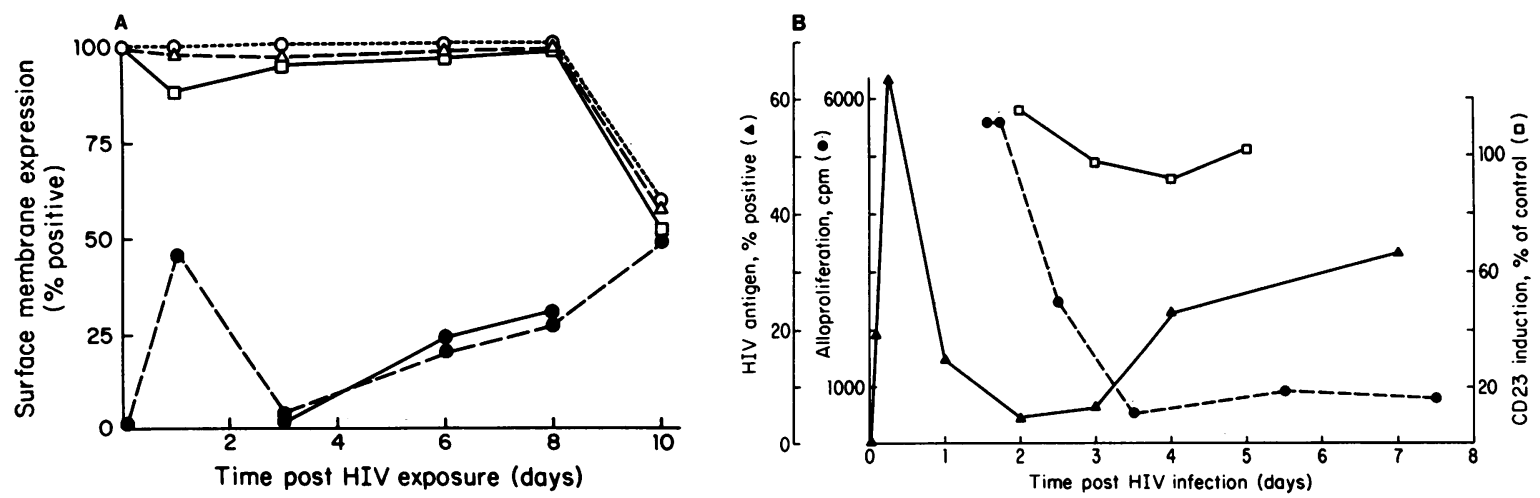

Figure 1. Effect of HIV on T cell receptor antigen complex expression and MHC-restricted immune reactivity. $(A)$ Clone 86 cells were exposed to $1,000 \mathrm{ID}_{50} \mathrm{HIV}$. Indirect immunofluorescence was performed over the next $10 \mathrm{~d}$ using antibodies directed against HIV epitopes (Sec, $\bullet---\bullet$; anti-gp120, - $\bullet$ ) and the CD3/Ti complex (anti-CD3 MAb, ० -.- ०; anti-T cell receptor complex MAb WT31, $\Delta---\Delta$; and anti-clonotypic MAb Ti-19.1, $\square-\left(\right.$ ). (B) Clone 86 cells were exposed to $1 ; 000 \mathrm{ID}_{50} \mathrm{HIV}$ for $2 \mathrm{~h}$ at $37^{\circ} \mathrm{C}$, washed, and maintained in medium containing $64 \mathrm{U} / \mathrm{ml}$ IL-2. Cell aliquots were removed at intervals and evaluated for HIV-specific proteins, proliferation to HLA-DR1 positive APC, and ability to induce CD23 expression on HLA-DR1 positive B lymphocytes. Results are presented as percent lymphocytes expressing HIV antigens by immunofluorescence with polyclonal antiserum $\mathrm{Cul}(\triangle)$, frequency of B cells staining with anti-CD23 MAb EBVCS2 as a percent of those in cultures unexposed to HIV (ם), or counts per minute of $\left[{ }^{3} \mathrm{H}\right]$ thymidine incorporation in cultures exposed to DR $1+$ APC (๑). Background fluorescence of parallel cultures not exposed to HIV was $\leq 0.6 \%$. Alloproliferation of uninfected 86 cells was $5,500 \mathrm{cpm}$. CD23 induction by an HLA-DR 1 negative APC was $<4 \%$. 
secretory assays were performed. (It should be noted that in our system clonal cultures were not restimulated with APC until aliquots were removed for testing. Spontaneous cell proliferation and thus cell concentration in infected or uninfected cultures naturally declined within $8 \mathrm{~d}$ after the last exposure to antigen.) In previous longer term experiments with these clonal cultures (2), in which refeeding with IL-2 and APC was permitted, total cell concentration did decline markedly by day 12 , with $152 \%$ viable cell recovery for untreated 86 cells, and $33.4 \%$ for the HIV-infected counterpart (2).

Effect of HIV on alloproliferation of 86 cells. At intervals of $2 \mathrm{~h}-7 \mathrm{~d}$ post-HIV exposure, 86-cell aliquots were removed and evaluated for HIV-specific proteins, reactivity to alloantigen, and activation by MAb Ti-19.1. Complete abrogation of proliferation to both alloantigen (Fig. $1 B$ ) and anti-clonotypic antibody (data not shown) was noted $4 \mathrm{~d}$ post-HIV inoculation.

Effect of HIV on phenotypic expression of $T$ cell surface membrane antigens. To ascertain whether antigen recognition was intact after HIV infection, it was important to determine whether expression of critical membrane receptor molecules was affected. The percentages of cells staining with reagents defining the $\mathrm{T}$ cell receptor complex (CD3, WT31, and Ti-19.1; Fig. $1 A$ ) were simultaneously evaluated. Nearly $100 \%$ of cells in control and HIV-infected cultures continued to stain with these antibodies at equivalent intensity through day 8.

Effect of HIV on CD-25 expression, CD-23 induction, and $I L-4$ secretion. In clone 86 high affinity IL-2 binding sites were found to be $<500$ per cell at a time point of maximal CD25 expression. Because of these low numbers of binding sites and considerable nonspecific background it was technically difficult to adequately compare HIV infected vs. uninfected cells by assaying for high-affinity ${ }^{125} \mathrm{I}-\mathrm{IL}-2$ binding. However, the IL-2 receptor alpha chain, assayed by CD25 expression, was clearly upregulated in both infected and control cells after exposure to alloantigen, suggesting that functional IL-2 receptors are indeed present after HIV infection.

86 cells in the resting state were $23.0 \pm 2.2 \%$ CD25 positive. Exposure to an irrelevant alloantigen led to a $<5 \%$ increase in CD25 expression. In the presence of HLA-DR1 APC the percentage of positive $T$ cells rose to $61.1 \%$ in control samples and $69.1 \%$ in HIV-infected cultures.

To determine whether antigen-specific functions other than proliferation were affected after HIV exposure, several MHC-restricted activities of these clones were examined. Despite the defect in DNA synthetic response to alloantigen induced by HIV (Fig. $1 B$ ), infected 86 cells were capable of fully inducing CD23 in B lymphocytes in an MHC-II antigen-specific fashion (Fig. $1 \mathrm{~B}$ ). This response is thought to be mediated at least in part by IL-4 $(7,8)$. We thus sought to determine whether HIV had an effect on generation and secretion of IL-4. Up to $7 \mathrm{~d}$ post-HIV infection no effect on IL-4 production in response to antigen-specific signals was detected. In A57b cells, the uncloned bulk culture from which A57 was derived, $<0.5$ $\mathrm{U} / \mathrm{ml}$ of IL-4 was produced in the presence of a non-HLADR2 APC, rising to $3.0 \mathrm{U} / \mathrm{ml}$ for uninfected cells and 4.5 $\mathrm{U} / \mathrm{ml}$ for HIV-infected cells in the presence of an HLA-DR2+ APC. In 86 cells HLA-DRI APC induced $5.5 \mathrm{U} / \mathrm{ml}$ in control cultures and 7.0 U/ml in cells exposed to HIV for $5 \mathrm{~d}$.

Effect of HIV infection on inositol lipid hydrolysis. The $\mathrm{CD} 3 / \mathrm{Ti}$ complex transduces extracellular stimuli across the plasma membrane, generating intracellular signals via phos- pholipase-dependent inositol lipid hydrolysis. This hydrolysis results in the formation of two second messenger molecules: inositol triphosphate, which causes an increase in intracellular free calcium ions $\left(\left[\mathrm{Ca}^{2+}\right]_{i}\right)$, and diacylglycerol, which serves as a cofactor in the activation of protein kinase $\mathrm{C}$ (PKC). To examine the effect of HIV infection on signal transduction, $\left[{ }^{3} \mathrm{H}\right]$ inositol phosphates were isolated. Table I demonstrates that enhanced inositol phosphate production was specifically induced by antigen, and unaffected by $\mathrm{HIV}$ at a time point $5 \mathrm{~d}$ after HIV exposure, when proliferation to alloantigen is completely blocked (Fig. $1 \mathrm{~B}$ ).

Effect of HIV on clonal expansion by antigen-nonspecific mitogenic signals. The possibility that the HIV-induced proliferative defect is specific to $\mathrm{T}$ cell activation via the $\mathrm{CD} 3 / \mathrm{Ti}$ complex was addressed using three methods of $T$ cell activation. The first involved reagents that interact with nonpolymorphic parts of the CD3/Ti complex (anti-CD3 MAb). The second involved binding of the CD2 ligand (anti-CD2 MAb) plus phorbol 12-myristic 13-acetate (PMA). The third used MAb against the CD28 molecule plus PMA (10). High concentrations of anti-CD3 MAb alone, or PMA in conjunction with either anti-CD3, anti-CD2, or anti-CD28 reagents, induced a blastogenic response in T helper cell clones (Table II). HIV infection completely abolished proliferation to all three signals by $4 \mathrm{~d}$ post-HIV exposure.

Since these clones are IL-2 dependent, produce large amounts of IL-4, and are also IL-4 responsive, we examined these ILs as potential sites of the HIV-induced defect. IL-2 production is minimal $(<0.5 \mathrm{U} / \mathrm{ml})$ and cannot be measured, but exogenous IL-2 failed to reverse the proliferative defect. This was true for both alloantigen- and MAb-mediated $\mathrm{T}$ cell activation (Fig. $1 B$ and Table II), all of which included 64 $\mathrm{U} / \mathrm{ml} \mathrm{IL}-2$, as well as separate experiments increasing the IL-2 concentration to $128 \mathrm{U} / \mathrm{ml}$ (data not shown). Similarly, 5 $\mathrm{U} / \mathrm{ml}$ recombinant IL-4 had no effect on bypassing the proliferative defect to alloantigen or anti-CD3 MAb.

Effect of $T$ cell activation on HIV replication. We sought to determine whether an enhancement of HIV replication consequent to the various mitogenic signals used might be responsible for the proliferative defects observed. Culture supernatants were solubilized in $0.5 \%$ Triton X-100 and HIV p24 core anti-

Table I. Effect of HIV on APC-enhanced Inositol Phosphate Formation in Clone 86 Cells

\begin{tabular}{lccc}
\hline $\begin{array}{c}\text { Culture } \\
\text { conditions }\end{array}$ & $\begin{array}{c}\text { HIV } \\
\left(1,000 \mathrm{ID}_{\mathrm{so}_{0}}\right)\end{array}$ & [ $\left.^{3} \mathrm{H}\right]$ Inositol phosphates & $\begin{array}{c}\text { Percent change } \\
\text { over control }\end{array}$ \\
\hline & & $c p m \pm S D$ & \\
$86+$ medium & - & $113 \pm 5$ & - \\
$86+\mathrm{DRI}^{-}$ & - & $104 \pm 14$ & 0 \\
$86+\mathrm{DRI}^{+}$ & - & $326 \pm 15$ & +288 \\
$86+$ medium $^{-}$ & + & $87 \pm 10$ & - \\
$86+\mathrm{DRI}^{-}$ & + & $73 \pm 8$ & 0 \\
$86+\mathrm{DRI}^{+}$ & + & $300 \pm 23$ & +344 \\
\hline
\end{tabular}

86 cells, uninfected or $4 \mathrm{~d}$ after exposure to HIV, were labeled with myo- $\left[{ }^{3} \mathrm{H}\right]$ inositol. $\left[{ }^{3} \mathrm{H}\right]$ Inositol phosphates were determined after $1 \mathrm{~h}$ of culture with the indicated stimuli. Values represent the mean \pm SD of triplicate cultures. Percent change over control is calculated relative to cells cultured with medium alone. 
Table II. Effect of HIV on Proliferative Responses of Clonal T Lymphocytes to Antigen-specific and -nonspecific Mitogenic Signals

\begin{tabular}{|c|c|c|c|c|c|c|c|c|}
\hline \multirow{3}{*}{ Clone } & \multirow{3}{*}{ Experiment } & \multicolumn{3}{|c|}{ Stimuli* } & \multicolumn{4}{|c|}{$\left[{ }^{3} \mathrm{H}\right]$ Thymidine incorporation ${ }^{\ddagger}$} \\
\hline & & \multirow[t]{2}{*}{ APC } & \multirow[t]{2}{*}{ MAb } & \multirow[t]{2}{*}{ PMA } & \multicolumn{2}{|c|}{ Control } & \multicolumn{2}{|c|}{ HIV-infected } \\
\hline & & & & & cpm & S.I. & $c p m$ & S.I. \\
\hline \multirow[t]{12}{*}{ A57 } & 1 & - & - & - & $141 \pm 18$ & 1 & $463 \pm 18$ & 1 \\
\hline & & irrel. + & - & - & $161 \pm 48$ & 1.1 & $459 \pm 40$ & 1.0 \\
\hline & & rel. + & - & - & $3,122 \pm 98$ & 22.1 & $539 \pm 23$ & 1.2 \\
\hline & & - & - & + & $161 \pm 48$ & 1 & $459 \pm 40$ & 1 \\
\hline & & - & $\mathrm{CD} 2$ & + & $2,307 \pm 393$ & 14.3 & $340 \pm 71$ & 0.7 \\
\hline & & - & CD3 & + & $1,706 \pm 128$ & 10.6 & $330 \pm 27$ & 0.7 \\
\hline & 2 & - & - & - & $284 \pm 95$ & 1 & $314 \pm 43$ & 1 \\
\hline & & - & CD3 & - & $1,623 \pm 127$ & 5.7 & $228 \pm 11$ & 0.7 \\
\hline & & - & - & + & $178 \pm 10$ & 1 & $506 \pm 166$ & 1 \\
\hline & & - & CD3 & + & $1,210 \pm 238$ & 6.8 & $337 \pm 14$ & 0.7 \\
\hline & 3 & - & - & + & $286 \pm 47$ & 1 & 297 & 1 \\
\hline & & - & CD28 & + & $1,945 \pm 560$ & 6.8 & $265 \pm 47$ & 0.9 \\
\hline \multirow[t]{7}{*}{86} & 1 & - & - & - & $254 \pm 78$ & 1 & $253 \pm 33$ & 1 \\
\hline & & - & $\mathrm{CD} 2$ & - & $236 \pm 82$ & 0.9 & $257 \pm 71$ & 1.0 \\
\hline & & - & - & + & $197 \pm 62$ & 1 & $218 \pm 8$ & 1 \\
\hline & & - & $\mathrm{CD} 2$ & + & $595 \pm 59$ & 3.0 & $167 \pm 12$ & 0.7 \\
\hline & 2 & - & - & - & $358 \pm 129$ & 1 & $222 \pm 54$ & 1 \\
\hline & & irrel. + & - & - & $394 \pm 92$ & 1.1 & $312 \pm 41$ & 0.9 \\
\hline & & rel. + & - & - & $2,222 \pm 788$ & 6.2 & $347 \pm 16$ & 1.6 \\
\hline
\end{tabular}

* MAbs were used as a 1:400 dilution of ascites (CD2 and CD28) or a 1:20 dilution of supernatant (CD3). PMA was used at $50 \mathrm{ng} / \mathrm{ml}$. Irradiated, E-rosette negative stimulator cells (APC) carried either the relevant (rel. APC) or irrelevant (irrel. APC) allodeterminant for the T cell clone examined. ${ }^{\ddagger}$ Cells, uninfected or $24 \mathrm{~h}$ post-exposure to $1,000 \mathrm{ID}_{50} \mathrm{HIV}$, were plated in round-bottom microwells in the presence of an equal number of irradiated APC, MAb, or PMA. Cultures were maintained for $3 \mathrm{~d}$, the last $18 \mathrm{~h}$ of which [ ${ }^{3} \mathrm{H}$ ]thymidine was added. All values represent the mean \pm SD of triplicate cultures. The stimulation index (S.I.) was calculated as (cpm of sample with stimulus)/(cpm of sample without stimulus).

gen levels measured by an antigen capture system (Abbott Laboratories, North Chicago, IL). At the early time points investigated there was no increase in extracellular virus related to any of the $T$ cell activation signals. In one experiment, supernatants contained $147.6 \mathrm{ng}$ of $\mathrm{p} 24$ antigen $/ 10^{6} 86$ cells at $6 \mathrm{~d}$ post-HIV exposure in the absence of a mitogenic signal. This is not significantly different from the $129.1 \pm 21 \mathrm{ng}$ detected in a series of six conditions of $\mathrm{T}$ cell activation (MAb plus PMA). In a second experiment, $47.4 \mathrm{ng}$ of p24 was detected under baseline conditions, unchanged from the $45.3 \pm 6.9 \mathrm{ng}$ found under 10 different conditions of mitogenic stimulation.

\section{Discussion}

HIV inhibits the proliferative response of helper $\mathrm{T}$ cells to alloantigen and other mitogenic signals. We sought to determine whether this defect was a consequence of receptor expression and antigen recognition, or occurred at more distal sites.

In our system, the initial afferent steps required for antigen recognition must be intact, as CD25 is upregulated, IL-4 secreted, and CD23 induced on B cells in an antigen-specific manner. In parallel, we found the CD3/Ti complex intact and inositol lipid hydrolysis in response to alloantigen increased normally despite HIV infection. These data support recent models suggesting that HIV binding through its gp120 outer envelope should be incapable of inhibiting MHC-II recognition events by helper $\mathrm{T}$ lymphocytes, even when bound to their CD4 structures (13).

The marked increase in CD25 expression, equivalent to uninfected control cells, when HIV infection was coupled with clonal activation, is also important as HIV infection decreases IL-2 mRNA and IL-2 secretion (14). However, exogenous IL-2 or IL-4 did not overcome the proliferative defects seen in our clones.

Use of IL-2-dependent human T cell clones such as 86 and A57 is particularly advantageous in terms of defining the mechanism of this alteration. Differences observed in transformed CD4+ T cell lines may not be physiologic. HIV infection of PBMCs create other problems, both because of the very low frequency of infected cells in such samples, typically peaking at $5 \%-15 \%$ by membrane immunofluorescence, and the presence of APC, which themselves may be infected and compound any change. These clones also permit comparisons with a related human retrovirus, human $\mathrm{T}$ lymphotropic virus type 1 , which alters $T$ cell alloreactivity in a different manner. Human T lymphotropic virus type 1 infection causes certain CD4+ $\mathrm{T}$ cell clones to proliferate nonspecifically to multiple class II determinants (reviewed in reference 2 ) even as other clones retain antigen specificity and cytolytic capacity (15).

The possibility that a suppressor factor or suppressor cell phenomenon was involved in the proliferative defect was also entertained. This hypothesis, by which a small number of 
HIV-infected cells would inhibit a much larger population of uninfected lymphocytes, was considered in our initial description of this clonal system (2), and again addressed. Cell-free supernatants from 86 cell cultures $4 \mathrm{~d}$ post-HIV exposure were added at a 1:3 or 1:9 final dilution (vol/vol) to fresh cultures of 86 cells and irradiated APC. No inhibition of alloproliferation was noted. Infected cells from similar 5-d cultures were added to uninfected cells at ratios of $1: 1,1: 4$, and 1:8, along with APCs, again without evidence for a suppressor cell phenomenon.

It is conceivable that the proliferative abnormality is due to altered metabolic events critical to signal transduction. Inositol lipid metabolism remained intact despite alterations in DNA synthetic response identified at these early time points. It is clear that later stages of infection reveal a variety of effects on lipid metabolic pathways, including increased triglyceride synthesis but decreased phosphatidylcholine and diacylglycerol (16). However, the inositol phosphates appear to be the key second messengers in our clones (12). Our data also suggest that altered signal transduction is not the cause of the proliferative defect, as other antigen-specific responses of our HIV-infected clones were left intact. Membrane potentials may be depolarized and baseline $\left[\mathrm{Ca}^{2+}\right]_{\mathrm{i}}$ increased in long-term HIV-infected T cell lines unresponsive to anti-CD3 MAb (17). Similarly, long-term (14-40 d) exposure of human T lymphocytes to HIV resulted in an inability to mobilize $\mathrm{Ca}^{2+}$ and an alteration in $\mathrm{CD} 3 / \mathrm{Ti}$ expression after stimulation with antiCD3 (18). In our clones, proliferative defects occurred much earlier after infection, and stimulation by way of CD28 would have been expected to bypass signal transduction via $\left[\mathrm{Ca}^{2+}\right]_{i}$ shifts, as it appears to function independently of CD3/Ti or alteration of $\left[\mathrm{Ca}^{2+}\right]_{i}(10)$. Our data with early HIV infection are also consistent with the lack of suppression of inositol lipid metabolism and calcium release in CD4+ cells exposed to HIV-1 envelope glycoprotein gp120 alone (19).

Finally, the relationship of the process of $T$ cell activation itself to the proliferative defect must be considered. The two models for $\mathrm{Ca}^{2+}$ mobility changes described above $(17,18)$ were complicated by large increases in HIV production coincident with stimulation of these chronically infected cells. Activated $\mathrm{T}$ lymphocytes produce a nuclear protein, NF-kappaB, which binds to an enhancer element in the HIV 5'-long terminal repeat (LTR) and increases viral gene expression in concert with the product of the tat transcription unit (20). The HIV LTR is also susceptible to stimulation by PHA- and PMA-induced products (21), and PMA itself augments HIV replication in a chronically infected CD4+ $\mathrm{T}$ lymphoblastoid cell line, leading to decreased cell growth and increased cytopathic effects (22). In contrast, we concentrated on much earlier time points after HIV infection and uncovered no enhancement of mature virion production.

We postulate that HIV regulatory genes are activated by direct LTR stimulation through all of the mitogenic signals used, all of which activate PKC. This could upregulate viral regulatory trans-acting factors before production of structural gene products. Qualitative defects without significant loss of viability could then occur in the absence of large amounts of HIV structural proteins, as high concentrations of envelope gp120 appear essential for cell death (14).

The identity of the transcription units that might be involved in these qualitative defects remains to be determined. Two attractive candidates are nef ( $3^{\prime}$-orf $)$ and $\mathrm{rev}(\mathrm{art} / \mathrm{trs})$. It is known that the protein products of these regions are phosphorylated subsequent to at least two types of activation signal we used (PMA plus anti-CD2 or PMA plus anti-CD28) (23, 24). Nef also appears to have a role in viral latency, augmenting HIV transcription when modified $(23,25)$. Indeed, while activation of PKC by inducers of phosphoinositol metabolism may have multiple effects on the level of HIV gene expression, HIV infection itself may positively alter expression of certain cellular genes. It appears to upregulate IL-1 $\beta$ (14) and B cell growth and differentiation factor-like activities (26), and our data suggest an increase in IL-4.

The relevance of our model of acute HIV infection to the situation in vivo requires further investigation. Certain studies indicate that functional $\mathrm{T}$ cell defects occur despite little demonstrable viral replication in vivo, with $<0.1 \%$ of the peripheral $\mathrm{T}$ cell pool containing HIV nucleic acid to the limits of in situ hybridization techniques (27). However, much greater numbers of cells may undergo low level chronic or latent infection, from which HIV may only be recognized after appropriate stimulation (14). Our findings do parallel proliferative abnormalities seen using $\mathrm{T}$ lymphocytes from early HIV-infected individuals (1), and may help to explain the lack of in vitro and in vivo efficacy of IL-2. In addition, our documentation of intact CD23 induction and IL-4 secretion despite other $T$ cell defects may be relevant to the hyperstimulation of $B$ lymphocytes characteristic of AIDS (14).

\section{Acknowledgments}

This work was supported by grants from the U. S. Army Medical Research Acquisition Activity (DAMD17-87-C-7020) and the National Institutes of Health (CA-42762 and CA-42046). Dr. Posnett is a Cornell Scholar in Biomedical Sciences.

\section{References}

1. Zolla-Pasner, S., D. C. Des Jarlais, S. R. Friedman, T. J. Spira, M. Marmor, R. Holzman, D. Mildvan, S. Yancovitz, U. Mathurwagh, J. Garber, W. El-Sadr, H. Cohen, D. Smith, V. S. Kalyanaraman, J. E. Kaplan, and D. B. Fishbein. 1987. Nonrandom development of immunologic abnormalities after infection with human immunodeficiency virus: implications for immunologic classification of the disease. Proc. Natl. Acad. Sci. USA. 84:5404-5410.

2. Laurence, J., J. Kulkosky, S. M. Friedman, D. N. Posnett, and P. O. P. Ts'o. 1987. Polyl.polyC12U-mediated inhibition of loss of alloantigen responsiveness and viral replication in human CD4+ T cell clones exposed to human immunodeficiency virus in vitro. J. Clin. Invest. 80:1631-1639.

3. Laurence, J., A. B. Gottlieb, and H. G. Kunkel. 1983. Soluble suppressor factors in patients with acquired immune deficiency syndrome and its prodromes: elaboration in vitro by $\mathrm{T}$ lymphocyte-adherent cell interactions. J. Clin. Invest. 72:2072-2081.

4. Goldberg, D., A. Green, A. B. Gottlieb, M. K. Crow, A. Lewison, and S. M. Friedman. 1985. Cloned allospecific human helper T cell lines induce an MHC-restricted proliferative response by resting B cells. J. Immunol. 135:1012-1018.

5. Friedman, S. M., and G. S. Thompson. 1983. Functionally restricted, allospecific, human helper $\mathrm{T}$ cell lines that amplify either B cell or cytolytic T cell responses. J. Exp. Med. 157:1675-1680.

6. Laurence, J., A. Saunders, and J. Kulkosky. 1987. Characterization and clinical association of antibody inhibitory to HIV reverse transcriptase activity. Science (Wash. DC). 235:1501-1504.

7. Crow, M. K., J. A. Jover, and S. M. Friedman. 1986. Direct T helper-B cell interactions induce an early B cell activation antigen. $J$. Exp. Med. 164:1760-1772. 
8. Defrance, T., J. P. Aubry, F. Rousset, B. Vanbervliet, J. Y. Bonnefoy, N. Arai, Y. Takebe, T. Yokota, F. Lee, K. Arai, J. de Vries, and J. Banchereau. 1987. Human recombinant interleukin 4 induces Fce receptors (CD23) on normal human B lymphocytes. J. Exp. Med. 165:1459-1467.

9. Martin, P. J., G. Longton, J. A. Ledbetter, W. Newman, M. P. Braun, P. G. Beatty, and J. A. Hansen. 1983. Identification and functional characterization of two distinct epitopes on the human $T$ cell surface protein Tp50. J. Immunol. 131:180-185.

10. June, C. H., J. A. Ledbedtter, M. M. Gillespie, T. Lindsten, and C. B. Thompson. 1987. T-cell proliferation involving the CD28 pathway is associated with cyclosporine-resistant interleukin 2 gene expression. Mol. Cell. Biol. 7:4472-4481.

11. Robb, R. J., W. C. Greene, and C. M. Rusk. 1984. Low and high affinity cellular receptors for interleukin 2: implication for the level of Tac antigen. J. Exp. Med. 160:1126-1146.

12. Chartash, E. K., A. Imai, C. Gershengorn, M. K. Crow, and S. M. Friedman. 1988. Direct human T helper cell-induced B cell activation is not mediated by inositol lipid hydrolysis. J. Immunol. 140:1974-1981.

13. Richardson, N. E., N. R. Brown, R. E. Hussey, A. Vaid, T. J. Matthews, D. P. Bolognesi, and E. L. Reinherz. 1988. Binding site for human immunodeficiency virus coat protein gp120 is located in the $\mathrm{NH}_{2}$-terminal region of T4 (CD4) and requires the intact variable-region-like domain. Proc. Natl. Acad. Sci. USA. 85:6102-6106.

14. Fauci, A. S. 1988. The human immunodeficiency virus: infectivity and mechanisms of pathogenesis. Science (Wash. DC). 239:617-622.

15. Faller, D. V., M. A. V. Crimmins, and S. J. Mentzer. 1988. Human T-cell leukemia virus type I infection of CD4+ or CD8+ cytotoxic T-cell clones results in immortalization with retention of antigen specificity. J. Virol. 62:2942-2950.

16. Lynn, W. S., A. Tweedale, and M. W. Cloyd. 1988. Human immunodeficiency virus (HIV-1) cytotoxicity: perturbation of the cell membrane and depression of phospholipid synthesis. Virology. 163:43-51.

17. Gupta, S., and B. Vayureguh. 1987. Human immunodeficiency virus-associated changes in signal transduction. J. Clin. Immunol. 7:486-489.
18. Linette, G. P., R. J. Hartzman, J. A. Ledbetter, and C. H. June. 1988. HIV-1-infected $T$ cells show a selective signaling defect after perturbation of CD3/antigen receptor. Science (Wash. DC). 241:573576.

19. Kornfeld, H., W. W. Cruikshank, S. W. Pyle, J. S. Berman, and D. M. Center. 1988. Lymphocyte activation by HIV-1 envelope glycoprotein. Nature (Lond.). 335:444-448.

20. Nabel, G., and D. Baltimore. 1987. An inducible transcription factor activates expression of human immunodeficiency virus in $\mathrm{T}$ cells. Nature (Lond.). 326:711-713.

21. Siekevitz, M., S. F. Josephs, M. Dukovich, N. Peffer, F. WongStaal, and W. C. Greene. 1987. Activation of the HIV-1 LTR by T cell mitogens and the trans-activator protein of HTLV-I. Science (Wash. DC). 238:1575-1578.

22. Harada, S., Y. Koyanigi, H. Nakashima, N. Kobayashi, and N. Yamamoto. 1986. Tumor promoter, TPA, enhances replication of HTLV-III/LAV. Virology. 154:249-258.

23. Guy, B., M. P. Kieny, Y. Riviere, C. Le Peuch, K. Dott, M. Girard, L. Montagnier, and J.-P. Lecocq. 1987. HIV F/3'orf encodes a phosphorylated GTP-binding protein resembling an oncogene product. Nature (Lond.). 330:266-269.

24. Hauber, J., M. Bouvier, M. H. Malim, and B. R. Cullen. 1988. Phosphorylation of the rev gene product of human immunodeficiency virus type 1. J. Virol. 62:4801-4804.

25. Luciw, P. A., C. Cheng-Mayer, and J. A. Levy. 1987. Mutational analysis of the human immunodeficiency virus: the orf-B region down-regulates virus replication. Proc. Natl. Acad. Sci. USA. 84:1434-1438.

26. Maggi, E., D. Macchia, P. Parronchi, M. Mazzetti, A. Ravina, D. Milo, and S. Romagnani. 1987. Reduced production of interleukin 2 and interferon-gamma and enhanced helper activity for IgG synthesis by cloned CD4+ T cells from patients with AIDS. Eur. J. Immunol. 17:1685-1690.

27. Harper, H. E., L. M. Marselle, R. C. Gallo, and F. Wong-Staal. 1986. Detection of lymphocytes expressing human $T$ lymphotropic virus type III in lymph nodes and peripheral blood from infected individuals by in situ hybridization. Proc. Natl. Acad. Sci. USA. 83:772-776. 